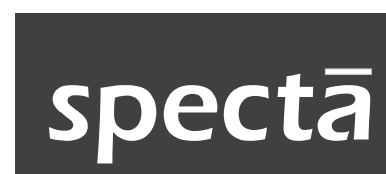

Journal of Photography,

Arts, and Media

Volume 1 Nomor 2 , November 2017: 149-162

\section{KAJIAN SEMIOTIKA TERHADAP MASKULINITAS DALAM FOTO IKLAN ROKOK GUDANG GARAM DJAJA EDISI 'RAHASIA DJAJA' TAHUN 2015}

\author{
Prasetyo Wicaksono Achmad \\ Irwandi* \\ Kurniawan Adi Saputro** \\ Fakultas Seni Media Rekam, Institut Seni Indonesia (ISI) Yogyakarta \\ Surel: insinyurwandi@yahoo.com
}

\begin{abstract}
Abstrak
Penelitian ini mengkaji makna foto iklan rokok Gudang Garam Djaja. Selain memiliki makna tersurat, sebuah foto iklan juga memiliki makna tersirat. Fotografi kerap kali digunakan seorang produsen untuk media ilustrasi iklan mereka, tak terkecuali bagi produsen rokok. Meskipun masyarakat telah mengetahui bahaya dan akibat yang ditimbulkan dari merokok, rokok tetap menjadi komoditas yang laku di tengah masyarakat Indonesia. Iklan secara langsung mempengaruhi hal tersebut, melalui iklan-iklan yang menjual produk rokok mereka kepada konsumen maupun calon konsumen baru, iklan ikut mempengaruhi persepsi pandangan mengenai rokok. Larangan penggunaan produk rokok secara vulgar melalui PP Nomor 81 Tahun 1999 menyebabkan produsen rokok untuk membuat konsep iklan yang tidak menggunakan atau menggambarkan kegiatan merokok sama sekali. Sering kali, foto iklan rokok menggunakan model maupun konsep yang menggambarkan imaji maskulinitas. Penelitian ini menggunakan metode kualitatif, di mana peran peneliti sebagai instrumen penelitian dan disajikan secara deskriptif. Metode yang digunakan dalam penelitian ini adalah metode semiotika konotasi. Melalui metode tersebut, akan ditemukan pemaknaan pada tingkat denotasi dan konotasinya. Hasil dari penelitian dapat ditarik kesimpulan bahwa konotasi yang menebal menjadi sebuah mitos dalam masyarakat. Imaji maskulinitas yang ditampilkan dalam foto iklan rokok Gudang Garam Djaja merupakan stereotip yang ada dan diyakini oleh masyarakat Indonesia pada umumnya.
\end{abstract}

Kata kunci: semiotika, maskulinitas, foto iklan, rokok

\begin{abstract}
Semiotics Study on Masculinity in the Advertising Photography of Gudang Garam Djaja Cigarette in 2015 Edition. This study examines the meaning of cigarette photo advertisement from Gudang Garam Djaja. In addition to having an explicit meaning, an advertising photo also has an implied meaning. Photography is often used by a manufacturer for their advertising illustration media, as well as for cigarette manufacturers. Although people already know the dangers and effects of smoking, cigarettes remain a commodity that sell in the Indonesian society. Advertising directly affects that, through advertisements which is selling their cigarettes to consumers and potential new customers, influences perceptions of views about cigarettes. The prohibition on the use of tobacco products vulgarly was stated in Government Regulation No. 81 of 1999 causes cigarette producers to conceptualize advertisements that do not use or describe smoking activities at all. Often, cigarette advertisement photos use models or concepts that portray images of masculinity. This research uses qualitative method, in which researcher role as research instrument and presented descriptively. The method used in this research is the method of semiotics connotation. Through this method, we will find meaning at denotation level and its connotation. The results of the study can be deduced that the connotation is thickened into a myth in society. The image of masculinity displayed in the photo of Gudang Garam Djaja cigarette advertisement is stereotyped and believed by people of Indonesia in general.
\end{abstract}

Keywords: semiotics, masculinity, photo ads, cigarettes

\footnotetext{
*Dosen di Program Studi Fotografi, Jurusan Fotografi, Fakultas Seni Media Rekam, ISI Yogyakarta

${ }^{* *}$ Dosen di Program Studi Fotografi, Jurusan Fotografi, Fakultas Seni Media Rekam, ISI Yogyakarta
} 


\section{PENDAHULUAN}

Media massa adalah sarana untuk menyampaikan berbagai macam informasi kepada masyarakat. Seperti yang dikatakan Sobur (2009:114) bahwa secara teoritis, media massa bertujuan menyampaikan informasi kepada masyarakat dengan benar dan efisien. Penggunaan media massa tidak terbatas pada berita aktual maupun konten yang bersifat hiburan, namun juga iklan yang berisi informasi mengenai produk atau jasa yang ditawarkan. Bahkan media massa mempunyai kemampuan untuk membentuk dan menggiring opini pubik dan dapat dipandang sebagai faktor yang menentukan proses-proses perubahan. Hal tersebut memberikan pemahaman bahwa media massa mempunyai pengaruh besar dalam merubah pola kehidupan masyarakat.

Menurut Sri Wahyuningsih (2013: 127), iklan adalah suatu bentuk komunikasi massa komersial yang dirancang untuk mempromosikan pemasaran suatu produk atau jasa, maupun pesan dari suatu lembaga, organisasi, bahkan bisa juga pesan dari seseorang yang mengkampanyekan tentang sesuatu.

Dunia periklanan yang berkembang pesat seiring dengan jaman, secara langsung mengakibatkan manusia dalam kehidupan sehari-hari selalu melihat iklan, mulai dari mereka beraktifitas ketika pagi hari hingga malam, manusia akan selalu dibayangi oleh iklan. Karena pada saat ini iklan telah ada di mana-mana, mulai dari televisi, surat kabar, internet, majalah, poster dan media yang lainnya, juga telah dimasuki oleh iklan.

Seiring pesatnya perkembangan jaman dan persaingan bisnis masa kini, semakin menuntut para produsen untuk saling beradu strategi demi meraih minat konsumen. Perang pun tak terelakkan, dari perang produk, harga, tempat, hingga promosi yang kerap dikenal dengan kegiatan pemasaran.
"Ditambah lagi masuknya unsur kapitalisme pada sendi-sendi industri, mengakibatkan barang diproduksi oleh pabrik dalam jumlah massal untuk mendapatkan laba sebanyak-banyaknya dengan cara menjual di pasar. Dalam sistem kapitalisme berbagai produk yang dihasilkan secara masal tersebut harus diupayakan agar segera diserap oleh pasar. Pemupukan produk tersebut karena tidak segera diserap pasar membawa dampak kerugian bagi produsen. Sebab dalam sistem produksi, penciptaan produk membutuhkan modal yang tidak sedikit". (Hamidah dan Sa'diyyah, Jurnal Ilmu Komunikasi, Vol. 1, No.2, 2011:236)

Para produsen menginvestasikan dana dalamjumlah besar demi menjalankan kegiatan promosi ini. Disamping produk pesaing yang serupa pun kian banyak bermunculan, para produsen harus meyakinkan konsumen untuk tetap memilih produknya. Maka dengan ini, makin ramailah pula perang pemasaran di kalangan produsen.

Konsep maskulinitas, seperti konsepkonsep lain dalam kehidupan telah terbangun secara simbolik oleh media. Sejak awal kehadiran media, maskulinitas identik dengan laki-laki yang mempunyai tubuh atletis, kuat, dan pemberani. Berbeda dengan feminim selalu digambarkan dengan lemah lembut, gemulai dan keibuan.

Maskulinitas dalam iklan juga digambarkan menggunakan tanda dan bahasa yang tidak bisa lepas dari budaya patriarki, bila laki-laki muncul dalam iklan, penokohannya digambarkan pemberani, agresif, jantan, mandiri, kuat, berkuasa, dan pintar. Konsep maskulinitas selalu digambarkan dengan tubuh berotot, dan tubuh berotot adalah tubuh yang paling ideal 
untuk menggambarkan "kelaki-lakiannya". Maskulin sebagian besar hanya diukur dari unsur sensualitasnya dan dapat diartikan bahwa maskulin sebagai sebuah barang yang sangat bermanfaat dan dipergunakan produsen dengan memberikan janjijanji dan solusi bahwa maskulinitas bagi laki-laki bisa didapatkan dari produk yang mereka tawarkan. Produk yang dihadirkan produsen untuk membantu dan memberikan dukungan pada masyarakat untuk mendapatkan ciri-ciri maskulin yang tujuan akhirnya untuk keuntungan bagi produsen atas produk tersebut. Salah satu contoh nyata iklan yang menggunakan konsep maskulinitas adalah iklan rokok.

Ada suatu kisah di kalangan para pekerja pabrik rokok, riwayat kretek bermula di Kota Kudus, dari penemuan Haji Djamhari pada kurun waktu sekitar akhir abad ke-19.

Kretek adalah temuan seorang kreatif dari Kabupaten Kudus bernama Haji Djamhari. Kisahnya, Haji Djamhari yang menderita penyakit bengek mengoleskan minyak cengkeh sebagai langkah pengobatan. Lantaran merasa kondisinya membaik, maka ia memotong cengkeh menjadi bagian kecil-kecil dan mencampur dengan racikan tembakau. Kretek... kretek... kretek... Haji Djamhari berhasil, bengek tak kambuh lagi. Dan lebih dari itu, ia berhasil memadukan dua komoditas penting hingga terciptalah sebuah produk asli Indonesia bernama kretek (Wibisono dan Yoandinas, 2014:12).

Eksperimen Haji Djamhari menjadi dagangan yang laris manis bagi Nitisemito selang kurun waktu sepuluh tahun kemudian. Bisnis rokok dimulai oleh Nitisemito pada 1906 dan pada 1914 usahanya resmi terdaftar dengan merk "Tjap Bal Tiga" dijual dalam kemasan. Jejak nitisemito pun diikutiperusahaan rokok lain di Kudus. Bisa dikatakan langkah Nitisemito itu menjadi tonggak tumbuhnya industri rokok kretek di Indonesia.

Gudang Garam merupakan salah satu raksasa perusahaan rokok bersanding dengan beberapa perusahaan rokok lainnya seperti Djarum, Dji Sam Soe, HM Sampoerna, dan Bentoel Grup. Perusahaan-perusahaan ini saling bersaing satu sama lain dalam pemasaran produk rokok mereka yang menyasar segmen pemuda, orang dewasa hingga orang tua. Dengan banyaknya pilihan produk rokok dari perusahaan-perusahaan tersebut, penggunaan iklan merupakan salah satu pemasaran yang efektif untuk menjaring pelanggan dan memperkenalkan produk rokok kepada para calon pelanggan baru.

Gudang Garam Djaja merupakan salah satu produk yang dikeluarkan oleh perusahaan Gudang Garam. Rokok ini merupakan jenis sigaret kretek tangan, merupakan salah satu produksi rokok kretek yang masih menggunakan proses manual. Ciri khas dari rokok jenis ini yaitu tidak ada filter rokok berwarna putih. Pada umumnya, penikmat rokok kretek lintingtangan ini merupakan para orang dewasa maupun warga senior karena karakter rokok yang kuat dan harum serta harganya yang murah.

Di Indonesia, kegiatan merokok dianggap hal yang lumrah dan wajar. Ini disebabkan kebiasaan para orang dewasa yang merokok di depan para anak kecil dan remaja. Ini menyebabkan mereka akan menganggap hal tersebut tidak berbahaya karena orang dewasa melakukannya. Beranjak remaja, merupakan masa-masa awal mereka mencoba rokok, pada akhirnya mereka merasa ketagihan dan sulit untuk berhenti merokok. The smokers perceived themselves as being addicted to tobacco, something that made quitting impossible $(\mathrm{Ng}$, et al., 2006:801). 
Sebuah mitos yang berkembang di kalangan remaja pada umumnya, jika mereka tidak ikut untuk merokok maka mereka tidak akan dianggap lelaki dan oleh karena itu mereka sama seperti wanita yang bersifat feminim. Rokok dalam hal ini dianggap sebagai sebuah simbol maskulinitas. Smoking is used as a metaphor for masculinity, potency, and bravery (Ng, et al., 2006:801).

Umumnyaiklan selalu menunjukkan gambaran produk dalam setiap tayangannya. Namun, trend iklan rokok cenderung tidak menampilkan produk, melainkan hanya pencitraan terhadap produk. Peraturan pemerintah nomor 81 tahun 1999 tentang pengamanan rokok bagi kesehatan merupakan peraturan yang melarang produsen rokok untuk menampilkan produknya berupa rokok, kegiatan merokok, dan segala sesuatu yang berhubungan dengan visualisasi rokok dalam setiap iklan yang tayang di masyarakat. PP Iklan tersebut tidak terbatas hanya pada berupa video iklan, namun juga foto iklan.

Dalam iklan cetak, fotografi lazim digunakan sebagai media ilustrasi dalam menyampaikan suatu iklan. Tampilan fotografi yang memiliki sifat riil semakin memudahkan persuasi bagi target audiens. Selain representasi produk, model yang memperagakan pesan yang dibawa oleh iklan juga akan terlihat semakin nyata(Harsanto, 2016:4).

Daya tarik sebuah foto iklan, baik yang bersifat komersial maupun non komersial harus mampu untuk memikat pemerhatinya yaitu masyarakat selaku sasaran dari produk dan atau jasa yang menyajikannya, karena pada sebuah foto iklan terdapat konsep desain yang bertujuan persuasif atau mengajak masyarakat selaku pemerhatinya untuk mengikuti keinginan desainer pembuatnya.

Dari pemaparan diatas, maka dalam penelitian ini akan membahas foto iklan Gudang Garam Djaja edisi Rahasia Djaja. Foto iklan ini merupakan iklan yang digunakan sebagai media promosi Gudang Garam Djaja pada tahun 2015. Masingmasing foto iklan Gudang Garam Djaja memiliki konsep yang berbeda.

Dari layout iklan yang digunakan sebagai obyek penelitian dalam penelitian ini, iklan-iklan tersebut merupakan iklan cetak luar ruang berupa billboard. Layout terlampir semua untuk ditayangkan melalui media luar ruang yaitu Billboard saja(Irawan, wawancara, 12 Juli 2017).

Dari iklan-iklan tersebut akan digunakan sebagai media mempromosikan produk rokok Gudang Garam Djaja di beberapa daerah tertentu saja. Karena memang konsumen terbesar rokok Gudang Garam Djaja ini terdapat didaerah-daerah tertentu saja seperti di Tegal, Lampung, dan sedikit area di Jawa Barat(Irawan, wawancara, 12 Juli 2017).

Foto iklan Gudang Garam Djaja mempunyai makna yang menarik untuk diteliti. Dari foto iklan tersebut, bila dilihat sekilas pandang, makna yang tersampaikan bersifat lugas dan langsung mengacu ke makna utamanya. Contohnya adalah foto iklan Gudang Garam Djaja edisi Rahasia Djaja versi Jaya Aromanya. Dalam foto tersebut terlihat sekelompok orangorang yang sedang menikmati sate, secara langsung tulisan jaya aromanya menggambarkan bahwa produk mereka Gudang Garam Djaja memiliki aroma yang menggoda. Namun, bila ditelusuri lebih jauh pemaknaannya, maka kita akan mendapatkan sebuah makna yang terkandung dalam foto iklan tersebut.

Untuk mengetahui sebuah makna 
ini, Peneliti hendak meneliti lewat hubungan antara tanda (Sign), penanda (Signifier), dan petanda (Signified), yang akan menuntun kita ke arah makna yang tersembunyi dari foto iklan rokok tersebut. Oleh karena itu, penulis merasa perlu untuk melakukan kajian semiotika foto iklan rokok Gudang Garam Djaja edisi rahasia djaja Tahun 2015.

\section{METODE PENELITIAN}

Penelitian ini merupakan penelitian deskriptif kualitatif, hasil dari metode penelitian kualitatif ini lebih berkenaan dengan interpretasi terhadap data yang ditemukan di lapangan.

Metode penelitian kualitatif sendiri adalah metode penelitian yang berlandaskan pada filsafat pospositivisme, digunakan untuk meneliti pada kondisi objek yang alamiah, (sebagai lawannya adalah eksperimen) dimana peneliti adalah sebagai instrument kunci, teknik pengumpulan data dilakukan secara trigulasi (gabungan), analisa data bersifat induktif/kualitatif, dan hasil penelitian kualitatif lebih menekankan makna daripada generalisasi (Sugiyono, 2012:9).

Objek yang akan diteliti dalam penelitian adalah foto iklan rokok Gudang Garam Djaja Tahun 2015. Foto iklan rokok tersebut memiliki kesamaan edisi iklan foto yaitu, edisi rahasia djaja.Iklan Gudang Garam Djaja edisi Rahasia Djaja pada periode tahun 2015 berjumlah 4 foto.

Dalam periode tahun 2015, Gudang Garam menggunakan foto iklan edisi rahasia djaja dengan total 4 foto dan masing-masing foto iklan tersebut memiliki konsep yang berbeda. Kemudian dari masing-masing foto akan dibedah dan dianalisa untuk dicari makna dan pesan menggunakan teori semiotika konotasi.
1. Teknik Pengumpulan Data

a. Studi Pustaka

Studi pustaka yaitu teknik pengumpulan data dengan cara memperoleh data dari karya ilmiah, berupa jurnal dan skripsi sarjana, serta buku yang berkaitan dengan penelitian ini.

Jurnal dan skripsi sarjana yang dikumpulkan berkaitan dengan penelitian ini yaitu, foto iklan rokok. Hal ini dilakukan untuk menemukan persamaan dan perbedaan serta penting untuk menyatakan bahwa penelitian belum pernah dilakukan sebelumnya.

b. Studi Dokumen

Pada penelitian ini studi dokumen yang dilakukan adalah dengan mengumpulkan foto-foto yang dikeluarkan oleh Gudang Garam Djaja untuk foto iklannya pada periode tahun 2015.Foto-foto iklan tersebut didapatkan berupa soft file dengan total 4 foto iklan edisi rahasia djaja, dan kemudian dijadikan sebagai bahan untuk penelitian.

\section{c. Wawancara}

Wawancara adalah bentuk komunikasi antara dua orang. Dengan melibatkan seseorang yang ingin mendapatkan informasi dari seseorang yang diasumsikan mempunyai informasi dengan mengajukan pertanyaanpertanyaan berdasarkan tujuan-tujuan tertentu (Mulyana, 2002:146). Dalam Penelitian ini, wawancara dilakukan kepada tim kreatif iklan. Hal ini dilakukan atas pertimbangan aspek informasi yang dimiliki oleh pihak yang diwawancarai. Informasi yang dimaksud antara lain, ide dan konsep iklan yang dibuat. 


\section{Fotografi Iklan}

Dalam menghasilkan foto iklan yang tepat sasaran, seorang fotografer akan mendapatkan arahan dari creative director. Creative Director adalah seorang individu yang berasal dari sebuah perusahaan advertising agency yang berperan menjembatani keinginan klien dan menghasilkan sebuah iklan yang dapat memuaskan klien. Keberhasilan suatu foto iklan sangat berpengaruh dari arahan creative director, di samping penguasaan teknis dan ide kreatif sang fotografer.

Dalam dunia fotografi komersial, foto iklan tidak terbatas hanya pada fotografi komersial pada umumnya seperti foto katalog, foto fashion, digital imaging, foto still life, dan lainnya. Fotojurnalistik bisa menjadi sebuah foto iklan bila tujuan dari pemasangan foto tersebut untuk mengiklankan suatu produk maupun jasa.

Meski menggunakan foto kejadian sebenarnya dalam iklan, esensi fotonya tetap jurnalistik. Namun, saat digunakan sebagai iklan untuk kepentingan advertising photography, maknanya menjadi lain. Tujuan publikasinya adalah menarik perhatian dalam muatan persuasif iklan, bukan menyampaikan berita untuk kepentingan umum. Apalagi, sentuhan digital imaging diperlukan dalam iklan untuk menguatkan tampilan estetisnya. Jadi, meskipun memiliki nilai berita, jika foto itu dipublikasikan untuk kepentingan iklan, konteksnya bukan lagi fotojurnalistik(Abdi, 2012:7).

\section{Semiotika Roland Barthes}

Teori semiotika Barthes dikembangkan dari teori penanda-pertanda yang dicetuskan Ferdinand de Saussure. Menurut Sobur (2004:46) yang cukup penting dalam upaya menangkap hal pokok pada teori Saussure adalah prinsip yang mengatakan bahwa bahasa itu adalah suatu sistem tanda, dan setiap tanda itu tersusun dari dua bagian yaitu signifier (penanda) dan signified (petanda), menurut Sausurre, bahasa itu merupakan suatu sistem tanda (sign).

Ferdinand de Saussure merupakan ahli linguistik yang lahir di Jenewa pada tahun 1857. Pemikirian Saussure tentang teori linguistik dan semiologi mengilhami Roland Barthes untuk mengemukakan teorinya mengenai semiologi. Dari pendekatan teori Saussure tersebut dapat digambarkan dengan skema sebagai berikut:

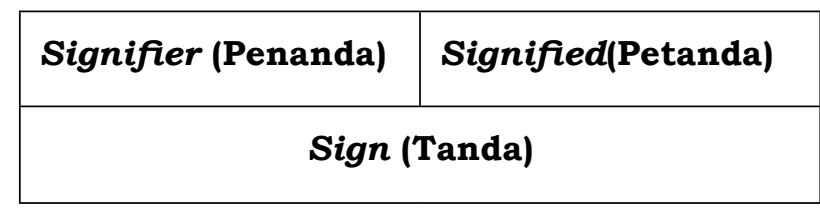

Gambar 1. Skema Semiotika Saussure

Dalam pendekatan teori yang dikemukakan oleh Barthes, ia membangun sistem tataran kedua yang disebut dengan konotatif, yang di dalam buku Mythologiesnya secara tegas ia bedakan dari denotatif atau sistem tataran pertama.

"Dalam mitos, sekali lagi kita mendapati pola tiga dimensi yang baru saja saya sebutkan: penanda, petanda, dan tanda. Namun mitos adalah salah satu sistem khusus, karena dia telah terbentuk dari serangkaian rantai semiologis yang telah ada sebelumnya: mitos adalah sistem semiologis tingkat kedua. Tanda (yakni gabungan total antara konsep dan citra) pada sistem pertama, menjadi penanda pada sistem kedua" (Barthes (Ed. Terjemahan), 2009:161).

Makna denotatif bukanlah sesuatu yang bisa dipastikan dengan tepat.Makna ini adalah generalisasi. Detail-detailnya berbeda dari satu medium ke medium lainnya, tetapi kualitas umum yang terkait masih tetap ada (Danesi, 2010:43).

Konotasi adalah mode operatif dalam pembentukan dan penyandian teks-teks kreatif. 
Dan tentu saja, semua teks dan genre media massa didasarkan atas konotasi, karena semuanya dirancang untuk membangkitkan makna yang signifikan secara budaya (Danesi, 2010: 44)

Untuk memahami lebih lanjut mengenai teori semiotika yang dikemukakan oleh Barthes, Ia membuat sebuah skema sebagai berikut:

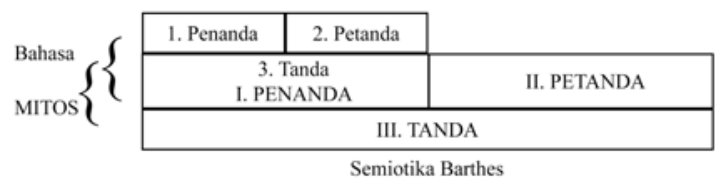

Gambar 2. Skema Semiotika Roland Barthes

\section{Maskulinitas}

Maskulinitas adalah imaji kejantanan, ketangkasan, keperkasaan/ keberanian untuk menantang bahaya, keuletan, keteguhan hati, hingga keringat yang menetes, otot laki-laki yang menyembul atau bagian tubuh tertentu dari kekuatan daya tarik lakilaki yang terlihat secara ekstrinsik (Jewitt, 1997).

Sifat-sifat maskulinitas yang dikemukakan oleh Deborah David dan Robert Brannon (Levine, 1998:145) adalah sebagai berikut:

\section{No Sissy Stuff}

Seorang laki-laki sejati harus menghindari perilaku atau karakteristik yang berasosiasi dengan perempuan.

2. Be a Big Wheel

Maskulinitas dapat diukur dari kesuksesan, kekuasaan, dan pengaguman dari orang lain. Seseorang harus mempunyai kekayaan, ketenaran, dan status yang sangat lelaki.

3. Be a Sturdy Oak

Kelelakian membutuhkan rasionalitas, kekuatan, dan kemandirian. Seorang lakilaki harus tetap bertindak kalem dalam berbagai situasi, tidak menunjukkan emosi, dan tidak memunjukkan kelemahannya.

4. Give Em Hell

Laki-laki harus mempunyai aura keberanian dan agresi, serta harus mampu mengambil risiko walaupun alasan dan rasa takut menginginkan sebaliknya.

\section{PEMBAHASAN}

\section{Analisis Foto Iklan Rokok Gudang Garam Djaja Edisi Rahasia Djaja Versi Jaya Aromanya}

a. Deskripsi Penanda (Signifier) dan Petanda (Signified) dalam Foto Iklan Rokok Gudang Garam Djaja Edisi Rahasia Djaja Versi Jaya Aromanya

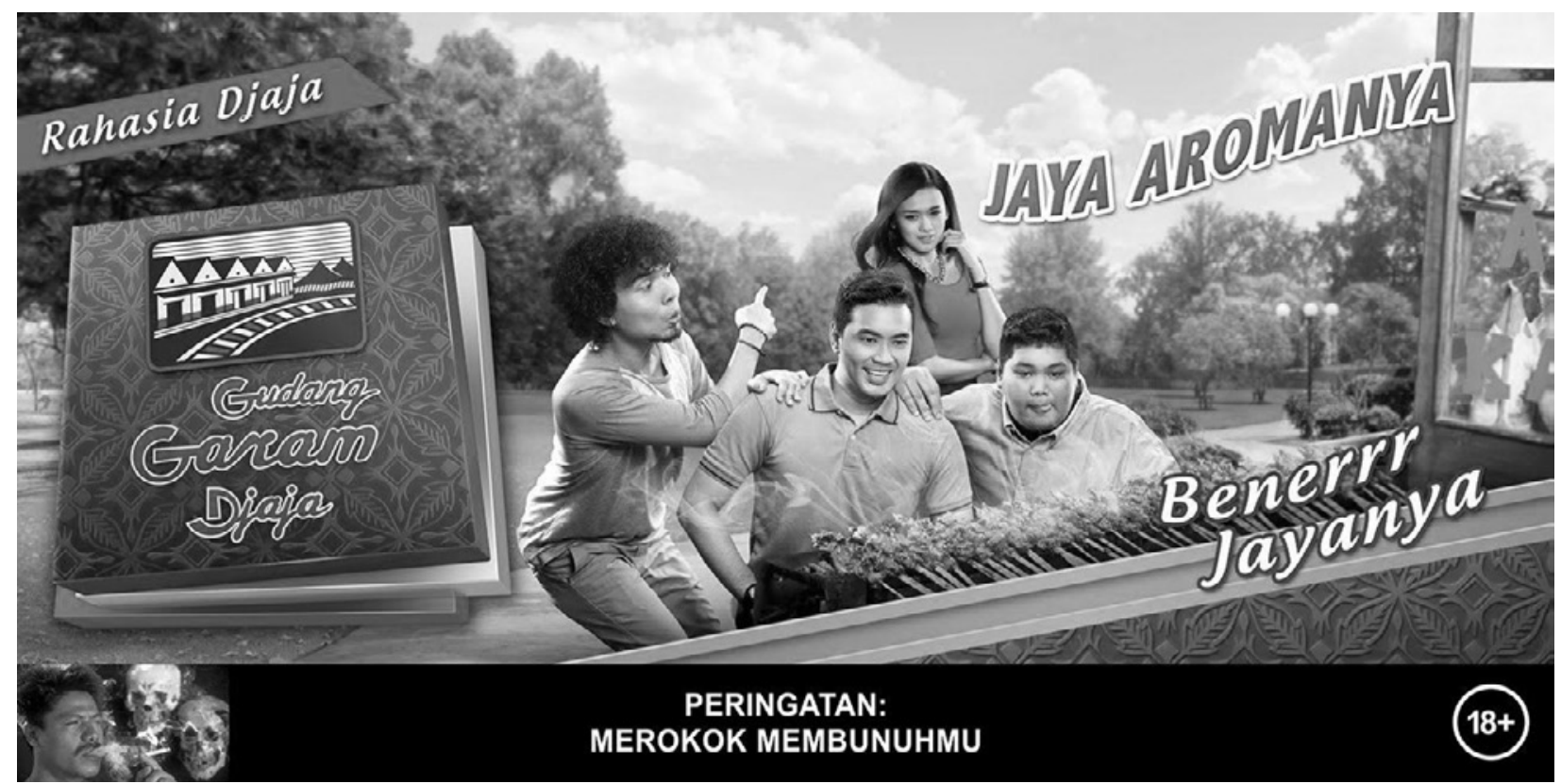

Gambar 3. Iklan Rokok Gudang Garam Djaja Edisi Rahasia Djaja Versi Jaya Aromanya 


\begin{tabular}{|l|l|}
\hline \multicolumn{1}{|c|}{ Signifier (Penanda) } & \multicolumn{1}{c|}{ Signified (Petanda) } \\
\hline 3 orang laki-laki & '3 orang laki-laki' \\
\hline Seorang wanita & 'Seorang wanita' \\
\hline Tempat pembakaran sate & 'Tempat pembakaran sate' \\
\hline Asap sate & 'Asap sate' \\
\hline Sate & 'Sate' \\
\hline Gerobak pedagang sate & 'Gerobak pedagang sate' \\
\hline Pohon-pohon berwarna hijau & 'Pohon-pohon berwarna hijau' \\
\hline & \\
\hline
\end{tabular}

Tabel 1. Klasifikasi Penanda dan Petanda pada iklan rokok Gudang Garam Djaja Edisi Rahasia Djaja Versi Jaya Aromanya

b. Makna yang Terkandung dalam Foto Iklan Rokok Gudang Garam Djaja Edisi Rahasia Djaja Versi Jaya Aromanya

Dalam menganalisis makna yang terkandung dalam foto iklan rokok Gudang Garam Djaja Edisi Rahasia Djaja Versi Jaya Aromanya secara keseluruhan, akan digunakan pemaknaan denotasi dan konotasi.

\section{1) Denotasi}

Pada tataran denotasi, foto iklan Rokok Gudang Garam Djaja Edisi Rahasia Djaja Versi Jaya Aromanya terdapat elemenelemen signifier (penanda) sesuai tabel diatas. Di foto terlihat 2 orang laki-laki yang sedang duduk dan 1 orang laki-laki yang berdiri. Di belakangnya terlihat seorang perempuan mengenakan baju berwarna merah sedang menatap ke arah sate. Dari gerak tangan seorang laki-laki yang berdiri, seakan memberitahukan ke 2 orang lakilaki yang duduk bahwasanya ada seorang wanita yang sangat "menggoda" di belakang mereka. Namun, hal ini tidak digubris oleh 2 orang laki-laki tersebut dan mereka tetap mengarahkan ketertarikan pada sate tersebut. Setting taman dapat dilihat dari adanya lampu taman bundar yang terlihat di latar belakang foto, ini didukung dengan rumput yang terpotong rapi. Warna langit yang cerah dan berawan menunjukkan suasana siang hari yang panas.

\section{2) Konotasi}

Di foto iklan tersebut, terlihat 2 orang laki-laki yang sedang duduk memandang ke arah sate, ini menggambarkan keteguhan hati. Laki-laki yang menggunakan pakaian berwarna hijau mempunyai makna bahwa ia yang menjadi point of interest dalam foto ini, karena dalam masyarakat, imaji seorang laki-laki ideal sering dikaitkan dengan postur tubuh proporsional.

Sate yang terlihat menggambarkan tujuan yang hendak dicapai dan asap sate yang terlihat dalam foto iklan tersebut menggambarkan aroma tujuan yang terasa nikmat. Penggunaan subjek sate karena dalam masyarakat Indonesia sate yang sedang dibakar memiliki aroma dan rasa yang lebih menggoda dari hal lainnya yang berada di sekitar mereka.

Imaji maskulinitas yang terlihat adalah keteguhan hati terhadap proses penantian dari kerja keras yang telah dilakukan dan menunggu hasilnya. Raut wajah senyum dan penuh kenikmatan terpancar dari wajah 2 orang laki-laki tersebut, gesture ini menggambarkan kegembiraan dan kesenangan bahwa tujuan atau keinginan mereka sudah berada di depan mata.

Seorang laki-laki yang sedang berdiri di samping sambil menunjuk ke arah seorang wanita yang sedang berdiri di belakang mereka, menggambarkan sebuah cobaan 
bagi mereka yang sedang menunggu hasil dari kerja kerasnya. Pada sistem masyarakat Indonesia, seorang lelaki dianggap lelaki bila ia memegang teguh terhadap pendiriannya dan tidak mudah terpengaruh, meskipun itu adalah teman terdekatnya sekalipun. Seringkali, seseorang tergoda oleh tujuan atau keinginan lain, sehingga ia mudah goyah dan tidak memiliki pendirian yang tetap.

Seorang perempuan berbaju merah yang berdiri di belakang para lelaki tersebut menggambarkan "godaan" yang tidak mungkin ditolak. Ini bisa dilihat dari penggunaan baju berwarna merah yang mencolok perhatian dan seakan ingin menjadi pusat perhatian. "Godaan" seperti ini sering ditemui dalam kehidupan sehari-hari sehingga sering seseorang mengubah tujuan atau keinginannya karena ia menganggap bahwa tujuan atau keinginan baru tersebut lebih "menggoda".

Posisi kedua laki-laki yang duduk sejajar, dan saling berdekatan tersebut menggambarkan bahwa untuk mencapai atau mendapatkan sesuatu yang diinginkan, akan terasa lebih menyenangkan bila itu dilalui dan dikerjakan bersama dengan teman. Pandangan yang tetap mengarah ke arah sate menggambarkan bahwa, meskipun mereka mendapatkan cobaan yang sangat menggoda, mereka tetap fokus dan berpendirian teguh pada tujuan mereka.Rasionalitas dan kekuatan merupakan sifat yang dimiliki oleh lelaki yang memiliki keteguhan hati.

Warna langit biru menggambarkan suasana di siang hari. Dapat diartikan bahwa mereka sedang membeli sate pada siang hari dan dapat dikatakan panas karena langit cerah menandakan sinar matahari langsung jatuh ke bumi tanpa ada yang menghalangi. Ini menggambarkan bahwa demi mencapai sebuah tujuan ataupun keinginan, seorang lelaki harus rela berjuang dan berusaha.

Setting taman dalam foto tersebut menggambarkan bahwa sesudah seorang laki-laki menentukan tujuannya, ia harus fokus terus pada tujuannya tersebut. Ini juga dapat menggambarkan bahwa seorang lakilaki harus bertindak kalem dalam usaha dan perjuangannya.

Pada foto iklan Gudang Garam Djaja Edisi Rahasia Djaja Versi Jaya Aromanya terdapat suatu makna yang mengandung makna seorang laki-laki harus memiliki keteguhan hati walaupun banyak cobaan dan godaan. Keteguhan hati ini penting bagi seorang laki-laki untuk meraih kesuksesan. Hal ini diilustrasikan melalui foto iklan rokok tersebut, dimana untuk meraih kesuksesan butuh teman agar terasa mudah dan menyenangkan. Dalam perjalanan tersebut, seorang lelaki pasti akan mendapatkan cobaan atau godaan, hal ini dapat menyebabkan tujuan awal berubah dan menyebabkan seorang lelaki menjadi tidak mempunyai pendirian.

Dari foto iklan rokok tersebut, Halhal yang diilustrasikan tersebut memiliki relasi dengan sifat maskulinitas yang telah dijelaskan di bab sebelumnya, yaitu sifat Be a Sturdy Oak.Sebuah perjuangan dan usaha yang dilakukan seorang laki-laki merupakan gambaran kekuatan laki-laki. Keteguhan hati dan fokus terhadap tujuan awal merupakan gambaran rasionalitas laki-laki serta menghadapi sebuah "godaan" seorang laki-laki harus tetap bertindak kalem dalam berbagai situasi.Rasionalitas, kekuatan, serta bertindak kalem dalam berbagai situasimemiliki relasi dengan sifat Be a Sturdy Oak.

Sifat maskulinitas Be A Sturdy Oak ini cocok digunakan dalam foto iklan rokok tersebut, karena ini berhubungan dengan sifat seorang laki-laki dewasa yang memilikirasionalitas, memiliki kekuatan, serta bertindak kalem dalam berbagai situasi. Ini cocok dengan pangsa pasar Gudang Garam Djaja yang menyasar mereka yang menginjak usia dewasa. Untuk menjadi seorang laki-laki yang dewasa, masyarakat Indonesia selalu 
menilai dari sifat yang ditunjukkan dalam hubungan bermasyarakat. Sifat tersebut merupakan kebalikan dari sifat labil seorang laki-laki remaja dan belum dianggap lelaki seutuhnya oleh masyarakat.

Produsen berusaha untuk menjual dan mempromosikan produk rokok Gudang Garam Djaja menggunakan sifat maskulinitas tersebut. Tulisan Jaya Aromanya merupakan gambaran dari aroma produk rokok tersebut yang memiliki aroma enak dan sedap, ini coba dijual melalui penggambaran imaji tujuan yang ingin dicapai memiliki aroma yang sama dengan aroma produk rokok tersebut, dimana gambaran ini sesuai dengan sifat maskulinitas yang telah disebutkan sebelumnya. Disini produsen berusaha menampilkan apabila konsumen maupun calon konsumen menggunakan produk mereka, Gudang Garam Djaja, mereka akan mendapatkan sifat maskulin tersebut.

\section{Analisis Foto Iklan Rokok Gudang Garam Djaja Edisi Rahasia Djaja Versi}

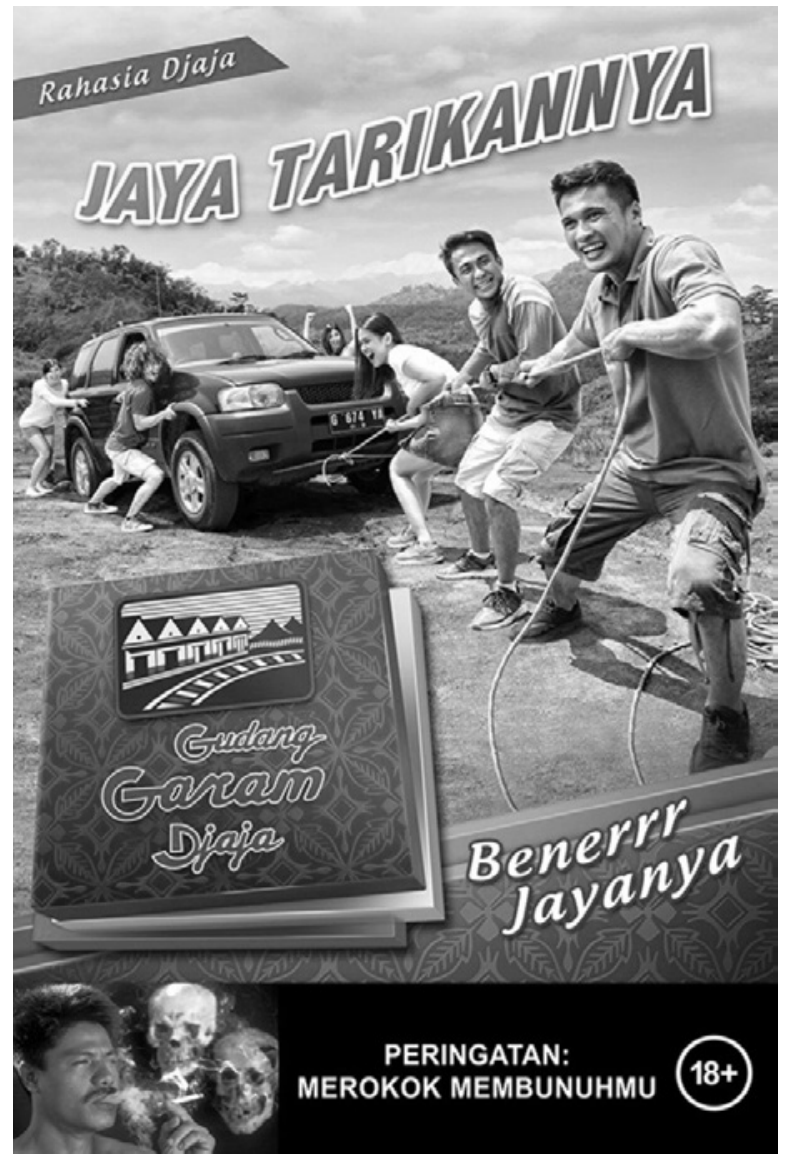

Gambar 4. Iklan Rokok Gudang Garam Djaja Edisi Rahasia Djaja Versi Jaya Tarikannya

\section{Jaya Tarikannya}

a. Deskripsi Penanda (Signifier) dan Petanda (Signified) dalam Foto Iklan Rokok Gudang Garam Djaja Edisi Rahasia Djaja Versi Jaya Tarikannya

\begin{tabular}{|l|l|}
\hline \multicolumn{1}{|c|}{ Penanda } & \multicolumn{1}{c|}{ Petanda } \\
\hline $\begin{array}{l}2 \text { orang laki-laki } \\
\text { menarik mobil }\end{array}$ & "2 orang laki-laki" \\
\hline $\begin{array}{l}1 \text { orang wanita } \\
\text { menarik mobil }\end{array}$ & $\begin{array}{l}\text { "1 orang wanita } \\
\text { menarik mobil" }\end{array}$ \\
\hline $\begin{array}{l}1 \text { orang laki-laki } \\
\text { mendorong mobil }\end{array}$ & $\begin{array}{l}\text { "1 orang laki-laki } \\
\text { mendorong mobil" }\end{array}$ \\
\hline $\begin{array}{l}1 \text { orang wanita } \\
\text { mendorong mobil }\end{array}$ & $\begin{array}{l}\text { "1 orang wanita } \\
\text { mendorong mobil" }\end{array}$ \\
\hline $\begin{array}{l}1 \text { orang wanita } \\
\text { memberikan } \\
\text { semangat }\end{array}$ & $\begin{array}{l}\text { "1 orang wanita } \\
\text { memberikan } \\
\text { semangat" }\end{array}$ \\
\hline $\begin{array}{l}\text { Sebuah mobil } \\
\text { berwarna hitam }\end{array}$ & $\begin{array}{l}\text { "Sebuah mobil } \\
\text { berwarna hitam" }\end{array}$ \\
\hline Tali kernmantel & "Tali kernmantel" \\
\hline Pegunungan & "Pegunungan" \\
\hline
\end{tabular}

Tabel 2. Klasifikasi Penanda dan Petanda pada iklan rokok Gudang Garam Djaja, Edisi Rahasia Djaja Versi Jaya Tarikannya

b. Makna yang Terkandung dalam Foto Iklan Rokok Gudang Garam Djaja Edisi Rahasia Djaja Versi Jaya Tarikannya

Dalam menganalisis makna yang terkandung dalam foto iklan rokok Gudang Garam Djaja Edisi Rahasia Djaja Versi Jaya Tarikannya secara keseluruhan, akan digunakan pemaknaan denotasi dan konotasi.

\section{1) Denotasi}

Pada tataran denotasi, foto iklan Rokok Gudang Garam Djaja Edisi Rahasia Djaja Versi Jaya Tarikannya terdapat elemen-elemen signifier (penanda) sesuai tabel diatas. Di foto terlihat 2 orang lakilaki yang sedang menarik tali kernmantel yang telah diikat ke mobil dan satu orang 
laki-laki yang ikut membantu dengan mendorong di sebelah pintu supir.Di foto iklan tersebut juga terlihat 1 orang wanita ikut menarik, lalu 1 orang wanita lainnya ikut mendorong mobil serta wanita lainnya yang hanya menyemangati di sisi lain mobil.Dari foto iklan tersebut, dapat dilihat bahwa rombongan tersebut sedang berusaha untuk mengeluarkan mobil yang sedang selip di lumpur.Setting luar ruang berupa wilayah pegunungan dapat terlihat dari latar belakang pegunungan dengan hutan yang lebat yang terlihat di kejauhan serta langit yang berawan.

\section{2) Konotasi}

Di foto iklan tersebut, terlihat 2 orang laki-laki yang sedang memegang tali kernmantel untuk menarik mobil serta 1 orang laki-laki yang mendorong mobil. Laki-laki yang berada paling depan digambarkan maskulinitasnya melalui imaji otot laki-laki yang menyembul serta keperkasaan.Laki-laki tersebut berada di posisi paling depan menggambarkan bahwa dia adalah point of interest dalam foto tersebut.

Selain itu, Laki-laki yang berada di belakangnya menggambarkan bahwa untuk menyelesaikan suatu permasalahan dibutukan seorang rekan yang siap membantu dalam keadaan suka maupun duka. Satu orang lakilaki yang berada di sebelah pintu kemudi menggambarkan bahwa seseorang harus memiliki pengaruh terhadap orang lain, karena untuk menyelesaikan sebuah permasalahan selain memiliki rekan yang dapat diajak kerja sama, juga dibutuhkan rekan untuk mengingatkan arah tujuan dan bertindak sesuai masalah yang dihadapi dan dapat dikendalikan.

Selanjutnya, terlihat di foto iklan tersebut 3 orang wanita. Wanita pertama terlihat bersama 2 orang laki-laki yang tadi, memegang tali kernmantel untuk menarik mobil yang selip. Wanita yang kedua terlihat berada di belakang mobil sedang mendorong mobil.2 Wanita ini menggambarkan bahwa seorang laki-laki tetap membutuhkan bantuan untuk menyelesaikan sebuah permasalahan. Wanita ketiga yang ada di foto iklan tersebut berada di balik sisi lain dari mobil tersebut. Tangan yang diangkat menandakan bahwa ia sedang memberikan semangat kepada temantemannya yang sedang menarik mobil, gesture tersebut juga menggambarkan optimis akan keberhasilan.

Tali kernmantel yang digunakan untuk menarik mobil tersebut menggambarkan cara-cara yang yang harus dilakukan untuk menyelesaikan sebuah permasalahan. Penggunaan tali kernmantel ini karena dalam dunia outdoor, baik itu olahraga outdoor maupun kegiatan outdoor seperti memanjat, menuruni tebing, selalu digunakan tali kernmantel. Tali ini digunakan karena kuat dan tidak mudah putus karena terburai serta mudah untuk disimpan tidak seperti tali jenis lainnya seperti tali serat alam.Ini menggambarkan untuk menyelesaikan sebuah permasalahan, kita harus mempunyai langkah-langkah yang efektif dan efisien.

Mobil yang mereka tarik menggambarkan suatu permasalahan yang hendak diselesaikan. Penggunaan mobil sebagai gambaran permasalahan menggambarkan setiap permasalahan memiliki resiko yang besar.Menarik sebuah mobil berukuran besar menggunakan tali bisa dibilang memiliki resiko yang besar. Tidak seperti di jalan aspal, dimana mobil dapat berjalan dengan mudah, di jalanan lumpur hal tersebut menjadi susah karena tenaga yang diperlukan dua kali lebih besar dari jalan aspal. Resiko seperti terkilir, mengalami luka di tangan, tenaga yang terbuang sia-sia serta lain sebagainya, dapat diminimalisir dengan rasionalitas serta kekuatan, sehingga sebuah masalah dapat diselesaikan. Oleh karena itu, dalam foto iklan tersebut digambarkan sebuah permasalahan dan seorang laki-laki digambarkan sebagai seorang pemimpin yang 
membawa kelompoknya keluar dari masalah tersebut.

Setting luar ruang berupa daerah pegunungan menggambarkan keadaan di dunia nyata, bisa berupa dunia kerja maupun organisasi dan lainnya, bahwa dunia tersebut keras dan tidak ramah kepada siapapun. Hal ini terlihat dari penggunaan imaji pegunungan dan hutan lebat yang berada di latar belakang.Pegunungan dan hutan lebat sering kali digambarkan sebagai tempat yang tidak nyaman, berbahaya bagi manusia, pentingnya kemampuan untuk bertahan hidup, serta kemampuan untuk bekerja secara berkelompok atau tidak egois.

Pada foto iklan Gudang Garam Djaja Edisi Rahasia Djaja Versi Jaya Tarikannya mengandung makna bahwa seorang lakilaki harus berani menantang bahaya untuk keluar dari sebuah permasalahan, selain itu seorang laki-laki juga harus mempunyai sifat kepemimpinan. Sifat berani menantang bahaya ini harus dibarengi dengan rasionalitas serta kekuatan, agar permasalahan tersebut dapat diatasi. Sifat-sifat yang digambarkan dalam foto iklan ini berbeda dengan sifat-sifat yang berhubungan dengan perempuan.

Dari foto iklan rokok tersebut, Hal-hal yang diilustrasikan tersebut memiliki relasi dengan sifat maskulinitas yang telah dijelaskan di bab sebelumnya, yaitu sifat No Sissy Stuff. Seorang laki-laki sejati harus menghindari perilaku atau karakteristik yang berasosiasi dengan perempuan memiliki relasi dengan sifat maskulinitas No Sissy Stuff.

Sifat maskulinitas No Sissy Stuffini cocok digunakan dalam foto iklan rokok tersebut, karena ini berhubungan dengan sifat seorang laki-laki dewasa yang harus menghindari sifatsifat yang sering diasosiasikan dengan wanita. Ini cocok dengan pangsa pasar Gudang Garam Djaja yang menyasar mereka yang menginjak usia dewasa. Untuk menjadi seorang lakilaki yang seutuhnya, masyarakat Indonesia selalu menganggap bahwa seorang laki-laki adalah mereka yang melakukan kegiatan di luar ruang, berpetualang, menjadi seorang pemimpin, berkeringat, mempunyai badan kekar serta menjauhi segala sesuatu yang berhubungan dengan sifat-sifat wanita pada umumnya.

Produsen berusaha untuk menjual dan mempromosikan produk rokok Gudang Garam Djaja menggunakan sifat maskulinitas tersebut. Tulisan Jaya Tarikannya merupakan gambaran dari tarikan produk rokok tersebut, ini coba dijual melalui penggambaran imaji menarik mobil keluar yang sedang selip karena proses ini membutuhkan tenaga lebih besar sama dengan rokok Gudang Garam Djaja yang memiliki tarikan rokok berisi dan berat. Ini tidak seperti jenis rokok sigaret kretek mesin maupun sigaret putih mesin yang dirasa tarikan rokoknya terlalu enteng, dimana gambaran ini sesuai dengan sifat maskulinitas yang telah disebutkan sebelumnya. Disini produsen berusaha menampilkan apabila konsumen maupun calon konsumen menggunakan produk rokok Gudang Garam Djaja, mereka akan mendapatkan sifat maskulin tersebut.

\section{SIMPULAN}

Setelah mengkaji dan menginterpretasikan foto iklan rokok Gudang Garam Djaja Edisi Rahasia Djaja Tahun 2015 dengan mencari makna yang terkandung dalam foto iklan tersebut, penelitian ini dapat disimpulkan sebagai berikut.

1. Sifat maskulinitas yang paling dominan dalam foto iklan rokok Gudang Garam Djaja tersebut adalah Be a Sturdy Oak. Pada umumnya, laki-laki yang memiliki sifat tersebut akan lebih disegani dan dipercaya oleh masyarakat Indonesia.

2. Dalam foto iklan rokok tersebut, didapatkan pemaknaan mengenai laki-laki. Konsep 
maskulin yang dihadirkan tersebut umumnya sejalan dengan stereotip seorang laki-laki dalam masyarakat Indonesia. Stereotip ini menebal menjadi mitos maskulinitas di tengah masyarakat Indonesia.

\section{KEPUSTAKAAN}

\section{Buku}

Abdi, Yuyung. Photography from My Eyes. Jakarta:ElexMediaComputindo,2012.

Barthes, Roland. Image Music Text. London: Harper Collin Publisher, 1977. - Mitologi, terj. Nurhadi dan A. Sihabul Millah. Rev.Ed.Yogyakarta: Kreasi Wacana, 1983.

Christomy, Tommy. Semiotika Budaya, Depok: PPKB Universitas Indonesia, 2004.

Danesi, Marcel. Pengantar Memahami Semiotika Media, Yogyakarta : Jalasutra, 2010.

Harsanto, Prayanto W. Retorika Visual Fotografis dalam Iklan Koran. Yogyakarta: Penerbit PT Kanisius, 2016.

Sobur, Alex. Analisis Teks Media; Suatu Pengantar untuk Analisis Wacana, Analisis Semiotik, danAnalisisFraming. Cetakan Kedua. Bandung:Remaja Rosdakarya, 2002. Semiotika Komunikasi. Bandung: Remaja Rosdakarya,2004.

Sugiyono. Metode Penelitian Kuantitatif Kualitatif dan R\&D. Bandung: Alfabeta. 2012.

Wahyuningsih, Sri, Desain Komunikasi Visual, Bangkalan, UTM Press. 2013.

Wibisono, Nuran dan Benny Prasetyo. Kretek: Kemandirian dan Kedaulatan Bangsa Indonesia, Perpustakaan Nasional: Katalog Dalam Terbitan (KDT), 2014.

\section{Jurnal}

Hamidah, Lilik dan Chalimatus Sa'diyyah. Analisis SimbolIklan RokokDjiSam Soe Gold Edisi Halus dan Mantap (Kajian Analisis Semiotik Pendekatan Roland Barthes), Jurnal Ilmu Komunikasi, Vol. 1, No.2 (Oktober 2011)
Jewitt, C. Images of Men: Male Sexuality in Sexual Health Leaflets and Posters for Young People, Sociological Research Online, vol. 2, no. 2, <http://www. socresonline.org.uk/2/2/6.html>

\section{Pustaka Laman}

Dimas. Gudang Garam Djaja, Skt Value For Money Dari Gudang Garam (http: / / reviewrokok.blogspot. co.id/2016/11/gudang-garamdjaja-skt-value-for-money.html, Diakses 8 Juli 2017) 